第七十巻第一号 人 類 學 亲隹 誌 昭和三十七年六月

\title{
三ケ日人と三ケ日只木石灰岩採石場の含化石層*
}

\author{
1. 三ヶ日人骨
}

鈴木尚

発端

三ケ日遺跡は静岡県引佐郡三ケ日町只木にある小規模な石灰岩採石場で、浜名湖の西北に 扣いて、独い水道で続く猪鼻湖の北岸に位置している（Fig. 1)。

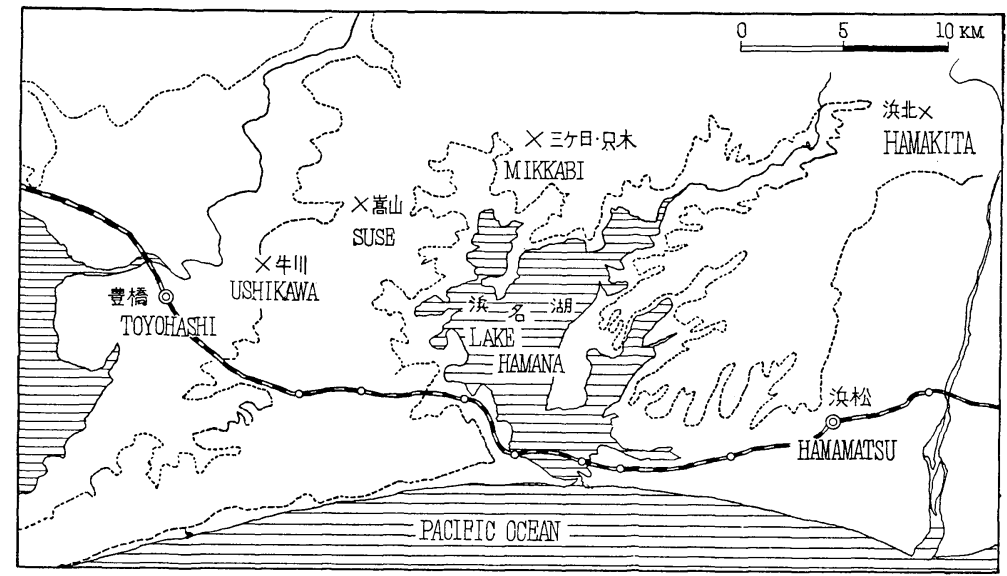

Fig. 1 Map of the site of Mikkabi, Shizuoka Pref. and relating sites around it. The dotted lines show contours $100 \mathrm{~m}$ above sea-level.

昭和 33 年 12 月、静岡目立三ヶ日高校教諭、高橋佑吉氏から高井冬二氏宛に、三ケ日町只 木の石灰岩採石場から獣骨化石が発見され、同校に保管されてある旨の連絡があり、高井氏 と筆者は翌34年 1 月 8 日、現地を訪れることになつたが、その際、多数の現生動物化石に混 つて、日本には既に死滅したひようの下顎骨 1 個を摘出した。

その後も両名によつてこの遺跡の監視が続けられたが、同年 9 月 15 日に行われた現地訪問 の際に、石灰岩の断崖に現われたフィツンャ一から (Fig. 2, E 3，×印)、偶然の機会にア オモリ象の牙に伴つて、人の右腸骨片が発見されたことを知つた。このフィツンャ一は垂直 の方向に走つていたが、その基底部 (Fig. 2, E 3) はほぼ水平に走る別のフィツンャーに連 絡し、当時な拉、その内部に赤褐色の角砂を含む砂質粘土が自然の状態で推積していたので、

* 長谷部言人博士喜寿記念論文

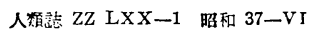

本研究は文部省科学研究費による。

(1) 


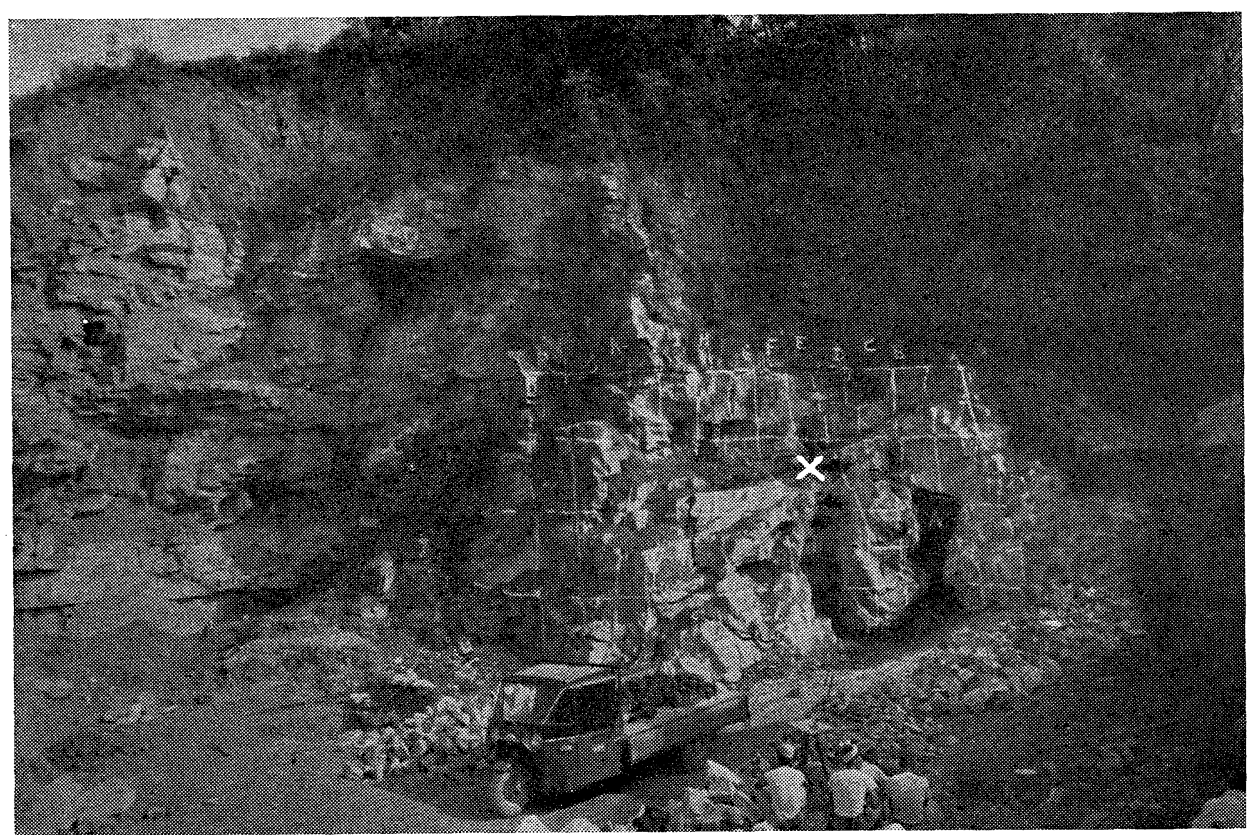

Fig. 2 The Site of Mikkabi, just before excavation. $\times$ Locality where a human iliac bone and an elephant tusk were found.

残余の人骨や獣骨の発見にもかなりの期待がもてそうに思われた。

このような判断にもとずき、同年 10 月 22 日から 10 日間に亘り、東京大学理学部人類学教 室执よび地質学教室高井研究室は三ケ日町、三ケ日高校、只木採石場などの協力を得て、前 記フィツンャ一内堆積の組織的発掘を行なつた。

発掘開始後 4 日を経た 10 月 25 日に至り、発掘直前の採石作業に際して捨てられた発掘地 点の堆積土の中から、よく化石した人の右側頭骨（No. 5）が発見された。これに打を得て 発掘を続行するうち、幸にして同 27 日から 29 日までの間にB 4 よりE 4 の範囲の含角礫砂 質粘土層から前頭骨 2 片（No. 1，2）頭頂骨 2 片（No. 3，4）が相次いで発見された。しか も後者の5 ち右頭頂骨（No. 3) は前記の右側頭骨片と正しく関節し、従つて両骨片は一個 体に属することが確認された。

越えて昭和 36 年 5 月 5 日、たまたま現地を訪問した節、採石作業中に発見された人の右側 大腿骨骨幹部 1 片とひよう下顎骨 1 片などが新規に採集され、ここに人骨は総数 7 片を数え ることになつた。これらの人骨は研究資料としてまだ充分とは云えないが．本遺跡における 採石作業も現在すでに峠を越えたと見られるので、吾及の調査研究も一応の区切りをつける 時期にあると考え、ここに各自その分担に従つて所見を述べをことになり、著者は三ケ日人 遺骨の研究を担当した。

\section{人 骨}

今日まで発見された人骨は総て7片であつて、頭骨として前頭骨 2 (No. 1，2）、頭頂骨 2 (No. 3，4)、側頭骨（No. 5) のほか骨盤（No.6）、大腿骨（No. 7) 各1片である。

これらの人骨はいずれも保存状態は良好で、よく化石している。 
人骨の記載の順序は、先ず形態学的な検討よりはじめ、ついで他の科学的手段による追求 に及ぶこととする。

\section{前頭骨 (人骨 No. 1)}

D 4 区の下半の高さで、含角碩砂質粘土層から発掘された。この骨は鱗部左後半を占める 横方向に長い不正四角形の骨片で、横径 $86 \mathrm{~mm}$, 前後径 $61 \mathrm{~mm}$, 淡黄褐色飞着色する。

冠状縫合はそのまま骨片の後縁をなすが、その鋸歯に融着のあとが認められない。また鋸 歯の形は当該縫合が本来簡単であることを考慮しても、な担つ簡単で、低く、OPPENHEIM の縫合型に従うとき、ブレグマ部は I-1、復雑部で I-3 である (P1. I, 1a, b)。

当該骨片の本縫合外側端は側頭縁の僅に外側に相当するのに対し、内側端は僅であるが頭 骨正中線を超えるものと判断される。

本骨片の内側縁は、はじめ正中線に沿つて走つたのち、外側に転じ。ついで前縁に移行し た後、発達の弱い前頭結節の頂点の約 $10 \mathrm{~mm}$ 前方に達すると、孤を画きつつ左側頭線を横 切り、外側縁に移行するので、全体として、注淔径 $40 \mathrm{~mm}$ の半円がつくられている。こ の半円の縁は人為的に整形されたように規則正しく、且つ滑で、半円の前後の終点は恰も chipping が行われたかの如き内板、外板の剥離を伴う切痕をなす。

骨の外面のうち注目すべきは側頭線である。本線はよく発達し、約 $5 \mathrm{~mm}$ の幅の隆起帯と なつているが、その経過に物いて冠状縫合線に比較的近く、したがつて、眼窩縁とはまだ相 当の距離をもつと推測される個所に於て、かなり強く外側に彎劰し、その frontotemporale は stephanion より $34 \sim 38 \mathrm{~mm}$ の距離にあるらしい。

この frontotemporale を境として、その前方部のうち、側頭線の外側部をつくる Fossa temperalis と内側部をなす煩骨突起の基部は、ともに現代人に見られるような、凸面をな すことなく逆に凹面を呈するから、破面で観察してと、雨者は側頭線で合する反りのある屋 根の状態を示している。

このことは、側頭線が現代人に於けるよりも早期に煩骨突起に移行し、従つてこの突起は 全体として外側に向つて張り出していたことが考えられるが、このような形は頓骨突起基部 拉よび側頭窩の形とともに、繩文時代人骨にしばしばみられるところである。

次に本骨片から前頭骨の全形を復原することは困難であるが全く不可能ではない。その際 飞決定すべき点は bregma, stephanion, frontotemporale 及び前頭結節の頂点であつて、 これらを基にするときほぼ次表の如き計測值が得られる。その際、比較のため同じ計測項目 飞関して繩文、古墳、現代人骨各 10 個について平均と最大、最小值を掲げた。

Table 1. Form of the frontal bone.

\begin{tabular}{|c|c|c|c|c|c|}
\hline & $\begin{array}{c}\text { Least frontal } \\
\text { breadth }\end{array}$ & $\begin{array}{c}\text { Max. front. } \\
\text { breadth }\end{array}$ & $\begin{array}{c}\text { bregma- } \\
\text { metopion }\end{array}$ & $\begin{array}{c}\text { stephan.- } \\
\text { frontotemp. }\end{array}$ & $\begin{array}{c}\text { Medio-saggital } \\
\text { frontal arc }\end{array}$ \\
\hline Mikkabi man & $(96)$ & $(111)$ & $(61)$ & $(38)$ & - \\
\hline $\begin{array}{c}\text { Prehistoric } \\
\text { Jomon man }\end{array}$ & $\begin{array}{c}97.7 \\
(93 \sim 107)\end{array}$ & $\begin{array}{c}120.5 \\
(113 \sim 135)\end{array}$ & $\begin{array}{c}74.7 \\
(68 \sim 83)\end{array}$ & $\begin{array}{c}48.0 \\
(41 \sim 50)\end{array}$ & $\begin{array}{c}125.2 \\
(118 \sim 133)\end{array}$ \\
\hline $\begin{array}{c}\text { Protohist. } \\
\text { Japanese }\end{array}$ & $\begin{array}{c}93.7 \\
(89 \sim 100)\end{array}$ & $\begin{array}{c}115.3 \\
(108 \sim 127)\end{array}$ & $\begin{array}{c}79.2 \\
(69 \sim 83)\end{array}$ & $\begin{array}{c}52.0 \\
(47 \sim 60)\end{array}$ & $\begin{array}{c}125.8 \\
(119 \sim 137)\end{array}$ \\
\hline $\begin{array}{c}\text { Modern } \\
\text { Japanese }\end{array}$ & $\begin{array}{c}93.5 \\
(91 \sim 97)\end{array}$ & $\begin{array}{c}109.8 \\
(104 \sim 120)\end{array}$ & $\begin{array}{c}79.3 \\
(76 \sim 87)\end{array}$ & $\begin{array}{c}53.8 \\
(48 \sim 58)\end{array}$ & $\begin{array}{c}129.7 \\
(120 \sim 137)\end{array}$ \\
\hline
\end{tabular}


三ケ日人は現代および古墳時代の日本人に比し、前頭骨幅径の割合に矢状径が短く、ほぼ 繩文時代人の関係に近い。

本骨片の内板には中硬脳膜動脈の Rr. frontales が冠状縫合の外側半を横切つて分枝する が内側半には認めることはできない。認められる限りに於て、これらはかなりの大血管であ るが、その分枝の状態に連続性がなく、印象の浱淡も平等でない。

\section{前頭骨（人骨 No. 2)}

本骨片はA 洞で、B 4 区下半の高さで、砂質粘土層から発見され、これに比較的近くCanis lupus の下顎と椅队押型文を有する早期繩文土器の小片 1 個が発見されている。

右眼窩上部を占ぬるほぼ三角形の骨片で、底辺は眼窩上縁、外側緑は右側頭線、内側縁は Glabella 中央より右上飞走る破面、上縁は注湔前頭結節の下に相当する (Pl. I, 2a, b)。

骨片は淡黄褐色であるが。内外面とも広範囲に黒色物質が附着するが、さらに頓骨突起縫 合面や他の破面氾認められる。

眉間及び眉上弓の隆起は強く、眼简縁は鈍で、外前切痕 Incisura frotalis lateralis の 幅は広く、ほぼ $5 \mathrm{~mm}$ を有し、これを外側より境する眼简縁は $10 \mathrm{~mm}$ に亘つて、軽度では あるが肥厚し、Processus supraorbitalis に近い外観を呈する。また切痕の内側縁にもこれ に近い肥厚がある。

Proc. zygomaticus は短いが、外側に向つて張り出し、その基部は平面的で、Planum supraorbitale とをなしている。

眼窝上壁の凹みは浅い。

骨片の内側には Sinus frontalis が全面的に露出するが、断面でみるとその前後両壁とも 著しく厚い。

最後に本骨片が既述の前頭骨と同一個体であるかという事については側頭線の形、planum supraorbitale と側頭窝の形、frontotemporale と前頭結節の位置の相互関係などに

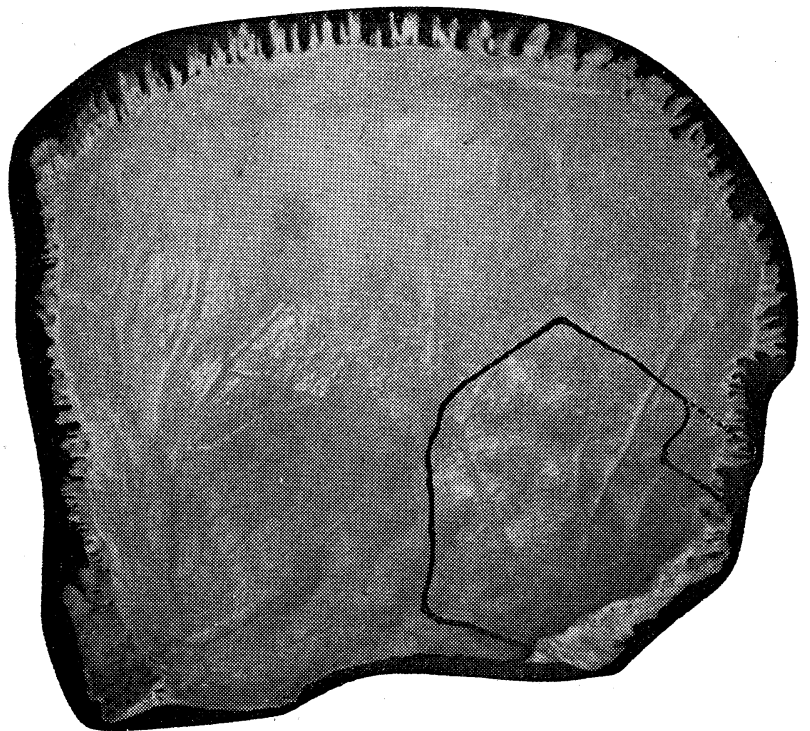

Fig. 3 The position of human bone No. 3 in the normal right parietal bone as seen from the inner surface.
関して、両者は一致しないので、 明に別の個体と考学る。本骨片 の性別に関しては正確なことは 云えないが、骨片に現われた特 徵は、繩文時代男性人骨と比較 してす、寧ろ弱いょうに思え る。この点から女性の可能性が 強い。

右頭頂骨（人骨 No. 3)

本骨片はE 4 区上半の高さか ら発掘された。

乳様角 (Angulus mastoideus）を含む頭頂骨後下隅を占 めるほぼ六角形の骨片で、その 最大径 $62 \mathrm{~mm}$, 最小径 $57 \mathrm{~mm}$ である (P1. I, 3a, b)。 
この六角形骨片のうち上位にある 3 辺は破面よりなるが、下位の 3 辺は縫合縁によつて形 成される。後者のうち、最前位にある前下縁は Margo squamosus の後部により、続く第 2 辺は Sut. occipitomastoidea, さらに後下辺は Sut. lambdoidea のアステリオン部によ つて構成される。これに対して上位 3 辺、すなわち前上、中上及び後上辺は破面によつて形 成されるが、その最高部は側頭線を僅に越える位置にあるらしい(Fig. 3)。

本骨片の外観は内外面て著しい相違が認められるが、これは人為的加工の有無と直接に関 係がある。

内 面

自然のますの形態を有し、したがつて通常の外観を有する中硬脳動脈溝の一部が認められ る。その走行は Angulus mastoideus に発し、lambda に向つて上行するところから、中 硬脳膜動脈後枝又は Ramus lambdaticus に相当することは明である。しかもこの後枝の 分枝状態は Ramus parietalis と見るべきものなく、僅に前枝との吻合枝とみられるものが あるだけである。また本幹の圧痕は通常よりも著しく浅いが、このことを考慮に入れても、 本血管が太かつたとは当抵考光られず、むしろ比較的細かつたと見なず゙きであろろ。

このように考えると、本血管は Foramen spinosum を出てから、直に前・後枝に分かれ

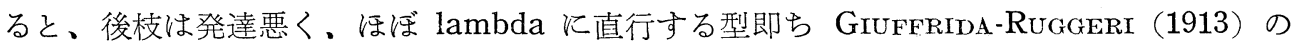
亚型に属するものと推定される。本型に属する中硬脳膜動脈は現代人に普通に見られる諸型 の一つであつて、欧州人で上記著者が検查したところでは男性 $24.3 \%$ 、女性 $29.5 \%$ 。男女 合計 $26.2 \%$ である。筆者が日本人で調査したところでは男女合計 $23.4 \%$ で、欧州人と相 違がなさそうである。

内面には、その注か、骨片の中央より寧ろ周辺部に当り、逆三角錐又は逆円錐形の小陥凹 が独立または密集して認められる。その径は 1 3 mm であつて、陷凹の尖底は丸い。この 形から、これらの陥凹が食肉動物の咬痕であることがわかる(P1. III, 8b)。

ここで興味のあることは骨片の周縁は至るところ cutting の跡が認められることである が、これは外面加工と関係があるので、その項で一括して述べることとする。

外面

内面と異つて、骨の色は著しく白味を帯びている。これはこの面が、余すところなく人為 的に研磨され、そのため骨は自然の外観を失い、光線を強く反射させるほで平滑化され、さ らにこのことは、骨片内板の彎曲よりも外板のそれを弱めている (P1. 3，8a)。

いま光線を反射させて、表面を観察すると、不規則な方向に走る線状の細痕が多数に認め られるが、これは研磨に際して生じたものと思われる。

さらに本骨片の周縁は部分的には研磨により、また部分的には鋭利な利器により削りとり ながら整形され、本骨片が何らかの意図のもとに骨器として利用されたことを物語つてい る。それにもかかわらず本骨片は全く自然の状態にある同側の側頭骨（No. 5) と鱗縫合 Sutura squamosa そ頭頂乳様縫合 Sut. parietomastoidea 介して解剖学的に正しく結 合をすることは、特記に值する事実である。

これら周縁の整形を以下に述べる方法で詳細に検討すると、加工者の意図を或る程度まで 推測することができる。

いま㑡頭骨の頭頂切痕 Incisura parietalis に粘土をつめこんで、加工前の頭頂骨乳様 
角 Angulus mastoideus の形を復原し、これと本骨片の相当部とを比較すれば、加工によ る細部の形態変化のみならず、加工の程度をも明にすることがでさる。すなわち、本骨片に おける6 辺の5ち、前下縁をなす Margo squamosus の薄い辺縁は、縫合に平行して $5 \mathrm{~mm}$ の幅に削りとられ、その断端は平滑な切面となつている。また鱗状縫合面は既述の外側面研 磨の延長として磨かれ、本来、稜と溝の組合せであるべき縫合鋸歯は、研磨のため消失して 滑にされている。その結果、側頭骨から復原される鱗状縫合基部の厚さは $6 \mathrm{~mm}$ であるが、 加工によつて $4 \mathrm{~mm}$ に減じていることを知つた（Fig. 3, Pl. III, 8)。

Sut. parietomastoidea によつて形成される中下辺も縫合鎕歯を基部から取り去る如く研 磨されているが、たまたま存在した側頭骨側の際立つて高い鋸歯に対応する深い凹みに対し ては、その前後を削ることにより傾斜が緩な切れ込みに変えている。さらに Angulus mastoideus の先端の内面は Pyramis 基部の上面に移行するため常に頭骨腔に向つて棘状に變 曲するが、本骨片ではこれをも削り去つている。また Angulus mastoideus から後方 S字 状湽 Sulcus sigmoideusに至る肥厚部に対して、この部分の縫合面の内側縁は $15 \mathrm{~mm} の$ 長さに亘つて斜に削られ、facet ができているが、その結果、中下辺は全長に亘つて同一の 厚さに整形されている(Pl. III；8 a,b,c)。

従つて、側頭骨より復原されるこの部分の骨の厚さは $11 \mathrm{~mm}$ であるが、本骨片では $7 \mathrm{~mm}$ に減じている。

後下辺はラムダ縫合アステリオン部によつて構成されるが、その上半分は破損のため欠除 しているが、残存する下半部でみると縫合に融着がなく、その鋸歯上には、既述の 2 辺ほど ではないが、研磨の跡が見觉る。

破面から成る骨片の上位 3 辺も下位 3 辺と同じく、その全長に亘り研磨されている。しか も各辺の移行部すなわち前上辺と中上辺、中上辺と後上辺の移行部は研磨によつて滑な形に 整形されているが、とくに両移行部のうち、前者が最もよく整形され、注ぼ円孤を画いてい る。

食肉動物による咬創は骨片の外面にも認められる。それらの場所は内面に相当している が、表面の研磨のため陌凹は内面のものより浅く、且つその縁は内面ほど鋭利でない。しか も前上辺と中上辺の移行点では、内面には多数の咬創を認めたのに、これに相当する外面に は全くこれを認めないのは、研籍のため消失したものと思われる。

このことは食肉動物が咬んだ後に、人によつて加工されたことを示するのであろう。

な和前上辺の後端に始まり、後上辺の後端に向いほぼ円孤を画く不鮮明な隆起は、その位 置から側頭線の名残と推測される。

以上に述べた右頭頂骨片の加工を要約すると：

骨の外表は全面に亘り研禁され、また骨の周縁は研磨と切削によつて整形されている。そ の際甚しく薄い部分或は影常な突起や肥厚部は除去して、全体として平等な厚さの縁にする 意図がうかがわれる。

食肉獣の咬創があるが、加工は受創後に行われた。

左頭頂骨（人骨 No. 4)

内側後端を占める不正四角形の骨片で、前後径 $58 \mathrm{~mm}$ 、横径 $54 \mathrm{~mm}$ 、淡黄褐色である。 骨片の内側縁は矢状縫合のオベリオン部 (Pars obelica) と後部 (Pars postica)、後縁は 
ラムダ縫合のラムダ部、前縁外側縁は破面でほぼ直線的走行をとる (Pl. I, 4a, b)。

矢状縫合鋸歯は両

部による形の相違は

なく、ともにOPPEN-

HEIM の I-3 型で、

何処沉も融着のあと を認めない。またオ ベリオン部の近傍に 頭頂孔を認めない。

中硬脳膜動脈の後 枝又は R. lambdaticus 乃至と机に必 敵するほどの血管 は、軽度の圧痕すら 認めず、わずかに末 端の小分枝が断続し

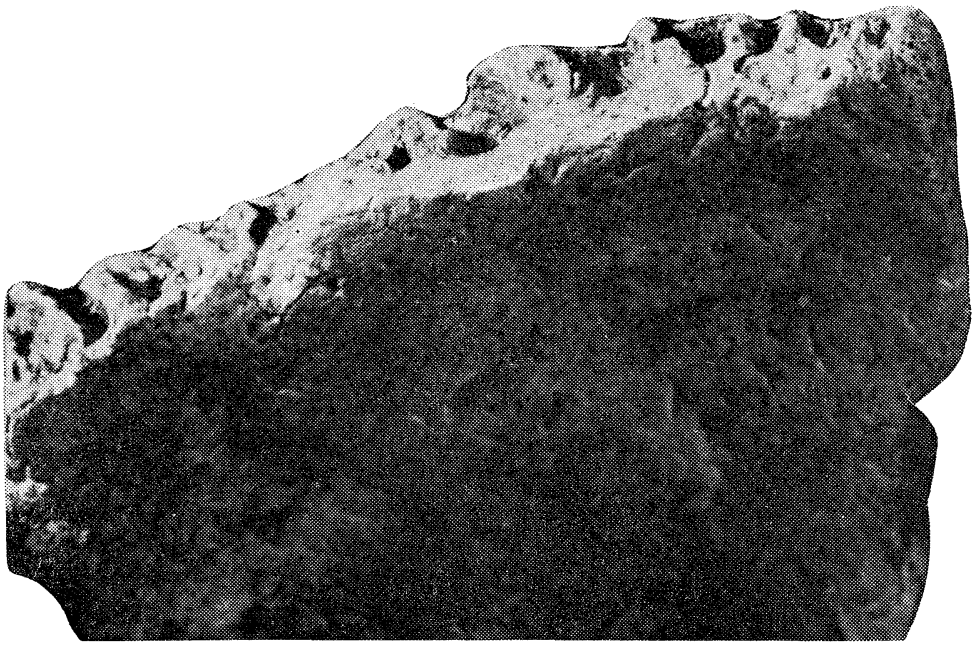

Fig. 4 Cut and polished margin of the right parietal bone, as seen from inside.

て部分的に現われるだけである。これは本幹の圧痕が右前頂骨と同様に、全体として甚だし く微弱であることを意味するであろう。

なお、本骨片の周縁の一部には、右前頂骨と同様な人為的と思われる加工部（切削）があ る。すなわち矢状縫合の Pars postica には異常がないが、Pars obelica では、その鋸歯 はその基部で切断されるのみならず、この部分の下縁の内板は約 $30 \mathrm{~mm}$ にわたつて斜に削 られ、そのため若干の小面が連続して認められる。同じ状態の加工はラムダ縫合にも見るこ とができる。また百に、前内側隅と前外隅は明に研磨されるが、とくに前者の内板が顕著で ある (Fig. 4)。

\section{右側頭骨（人骨 No. 5)}

本骨片は発掘着手の直前、採石作業に際して、D〜 F 区から掘り出された堆積土の捨場で、 偶然、人夫の 1 人によつて発見されたものであるが、前記の右頭頂骨（人骨 No. 3 ） と縫合 を介して正しく接合し、同一個体に属することがわかつた (Pl. II, 5a, b)。

乳様部と岩様部とはよく保存されているが、鱗部の大部分は欠損している。すべての縫合 に融着を認めない。

頓骨突起はFossa mandibularis の前縁に相当する位置で折れる。この乫起の上縁は鈍で あるが、破面の僅か後方でよく発達する 2 枝に分れる。そのうち 1 枝は上行するが、15 mm ほぞで急速に消失する。他の 1 枝は後走するもので、比較的よく発達した Crista zygomatica として外耳孔上部を通り、Crista supramastoidea に移行する。この Crista も亦よ く発達し、その棱線を境として、前部は恰も深くえぐり取られたように凹彎しつつ、Fossa temporalis に移行する。

これに対して稜線の後部は凸彎するが、乳様乫起基部とはよく発達した Sulcus supramastoideus によつて分離される。

乳様乫起の先端は欠ケているが、残存する部分から判断すると、突起はよく発達し、且つ 
外側に向つて膨隆しつつ、垂直に下垂するもののようである。

突起の内側面も広範团に欠損しているが、現代人に普通に見られるように突起の内側半が Incisura mastoidea によつて平に切り取られたよらである。さらにこの切痕す Homo sapiens に普通に見られる甚だ狹く且つ深い型のものである。

外耳孔は上下に長い楕円形で、その軸は僅に前傾する。さらに、外耳孔の遊離縁は甚だ薄 く、Spina supra meatum はよく発達する。Tympanic plate はほとんで垂直に下垂し、 その前面は凹彎し、その基部に近く、凹彎の底には裂隙状の小孔があるが、HUSCHKE 氏孔 の残りと考兄られる。

Pyramis は屈曲することなく真直に前内側に向う。Pyramis の Margo superior は鋭 い縁となり、その前面は凹凸を示すが、なかんずく Eminentia arcuata は高く隆起する。 また Fossa subarcuata 又はImpressio cerebellaris は甚だしく深く、ほとんど指頭が収 まるほどである。STRAUS（1960）によると本窩は primates にはよく発達するが、類人猿 や人類では消失飞傾きつつあるもので、特飞進化の点で重要ではないという。

頭 骨の厚さ

三ケ日人頭骨 No. 1，3，4，5 骨片は、後述するようは同一個体に属すると考学られるの で、これらについて頭骨の嬮さを計測し、他の資料と比較すると Table 2 の通りである。

三ケ日人は現代より一般に厚い頭骨壁をもつている。しかし北京人類より渚しく薄く、部 分的にはほぼ1/2の厭さであるが、Neanderthal とは僅の相違に渦ぎないし、Ordos 人とも 著しい差はないようである。

Table 2. Thickness of the skull fragments of Mikkabi Man.

\begin{tabular}{|c|c|c|c|c|c|c|c|c|c|}
\hline & \multicolumn{3}{|c|}{ Frontal } & \multicolumn{4}{|c|}{ Parietal } & \multicolumn{2}{|c|}{ Temporal } \\
\hline & Bregma & $\left|\begin{array}{l}\text { Tuber } \\
\text { front. }\end{array}\right|$ & $\begin{array}{c}\text { Facies } \\
\text { temp. }\end{array}$ & Bregma & $\begin{array}{l}\text { Tuber } \\
\text { pariet. }\end{array}$ & Asterion & Lambda & $\left|\begin{array}{c}\text { Squama } \\
\text { temp. }\end{array}\right|$ & $\begin{array}{l}\text { Fossa } \\
\text { mand. }\end{array}$ \\
\hline $\begin{array}{l}\text { Sinanthrop. } \\
\text { pekinensis }\end{array}$ & - & 9.3 & 5.3 & 8.8 & 10.8 & 14.8 & - & 8.0 & - \\
\hline Neanderthal & - & 6.8 & 4.5 & $\begin{array}{l}7.7 \\
6.5\end{array}$ & 9.0 & 7.3 & 二 & 6.5 & - \\
\hline $\begin{array}{c}\text { Mikkabi } \\
\text { man }\end{array}$ & $8 . \overline{2}$ & $5 . \overline{5}$ & 3.0 & 8.2 & 5.8 & $7 . \overline{5}$ & 8.0 & - & 4.5 \\
\hline Predmost & $\begin{array}{r}4 \sim 7 \\
8\end{array}$ & $3 \sim 6$ & $-\overline{3}$ & $-\overline{8}$ & $5 \sim 8$ & $4 \sim 12$ & $\overline{7}$ & $\overline{2}$ & - \\
\hline $\begin{array}{l}\text { Modern man } \\
\text { (MARTIN, } \\
\text { SAILER, 1959) }\end{array}$ & - & $5.8 \sim 6.3$ & $1 \sim 2$ & 5.5 & $2 \sim 5$ & $4.5 \sim 5.2$ & 6.0 & $1.3 \sim 2.5$ & $1 \sim 3$ \\
\hline
\end{tabular}

右腸骨 (人骨 No. 6)

今回の発掘の端緒をなしたもので、Paleoloxodon aomoriensis の牙とともに作業中人 夫によつて偶然発見されたが、発見者の証言によると。骨片はE 3 区のフイッンャ堆積内で 象牙より $15 \mathrm{~cm}$ 下から発見されたという。

本骨片は右腸骨前半部であつて、後方は腸骨櫛に执いて前上䊂より $40 \mathrm{~mm}$ 後方から、耳 状面前縁の僅か後方にかけて引いた直線に相当して折れ、下方は Eminentia iliopectinea から Spina ischiadica のわずかに上方にかけて引いた直線汇相当して破面があり、坐骨と 恥骨とはほとんど欠除している(P1. II, 6a, b)。

保存状態は一般に良好で、Crista iliaca に若干の咬痕らしい古い損傷があることを除け 
ば、原形をよく保存している。

腸骨は全体として現代日本人の形態と根本的な差異はない。

腸骨前縁は現代人に普通に見られるように「く」の字形に屈曲するが、その厚さの部分的 な相異は著しくない。すなわち、腸骨前上棘と同前下棘の発達はむしろ悪い方であるのに、 両棘間の前縁は比較的に厚くて鈍である。また腸骨櫛も通常現代人に見られるよ5な著しい 肥厚はなかつたようである。寛骨臼は長径、幅径に比して深く、その边縁は現代人に比して 幾分厚くて鈍に終つている。

腸骨窝はかなり深かつたと思われるばかりでなく、腸骨高は孤線の長さに比して高く、且 つ大坐骨切痕は鋭角であり、寛骨臼後縁の最高点から体部の内側面までの体部厚径が大きい $(35 \mathrm{~mm})$ ことなどから、本骨片の性別は男性と見做される。それにもかかわらず寛骨臼の幅 径は $44 \mathrm{~mm}$ であるから、高径は $44 \mathrm{~mm}$ か或は幾分大きいと推測されるので、男性の高径 最小值 $47 \mathrm{~mm}$ (新井)上り更に小さく、女性の最小值 $42 \mathrm{~mm}$ (新井)に近いことは、腸骨前上 棘頂点と同前下棘直下゙まで測つた腸骨翼前縁の高さが $45 \mathrm{~mm}$ で女性の最小值 $46 \mathrm{~mm}$ (長谷 部)に近いことともに、本骨盤の所有者は甚だ小柄な男性であつたことを示すものであろう。

いま具体的に三ケ日人の大きさを考光るため、吾国の洪積世人類の寛骨臼、大腿骨頭に関 して現代日本人と比較すると、Table 3 の通りである(注)。仮に現代人に於ける大腿骨最大 長とその骨頭と寛骨臼の大さの関係が、そのまま洪積世人にまで適用されるとすれば、三ケ 日人の寛骨臼の形から大腿骨の骨頭の大さや最大長の概略を推定することができる。

Table 3. Maximum length of the femora of Mikkabi and Ushikawa Man estimated from the dimensions of the acetabulum and caput femoris. * Measured from the cast.

\begin{tabular}{|c|c|c|c|c|c|}
\hline & \multicolumn{2}{|c|}{ Acetabulum } & \multicolumn{2}{|c|}{ Caput femoris } & \multirow{2}{*}{$\begin{array}{l}\text { Max. length } \\
\text { of the femur }\end{array}$} \\
\hline & $\begin{array}{c}\text { Transv. } \\
\text { diam. }\end{array}$ & Vert. diam. & $\begin{array}{c}\text { Transv. } \\
\text { diam. }\end{array}$ & Vert. diam. & \\
\hline \multirow{6}{*}{$\begin{array}{l}\text { Neanderthal man* }(\delta) \\
\text { Akashi* }(\delta) \\
\text { Mikkabi No. } 6(\delta) \\
\text { Ushikawa No. } 2(\delta) \\
\text { Modern Japanese }\left\{\begin{array}{l}(\delta) \\
(\delta)\end{array}\right.\end{array}$} & - & L. 62 & R. (53), L.53 & R. 54, L. 54 & R. 444, L. 446 \\
\hline & - & 50 & - & - & - \\
\hline & 44 & $(44+)$ & $(37.9)$ & $(37.9)$ & $(338.8)$ \\
\hline & $(47.4)$ & $(47.4)$ & 41 & 41 & $\mathrm{~F}(366.5)$ \\
\hline & - & $\begin{array}{c}53.2 \\
(47 \sim 59)\end{array}$ & $\begin{array}{c}45.8 \\
(40 \sim 52)\end{array}$ & $\begin{array}{c}46.1 \\
(40 \sim 52)\end{array}$ & $\begin{array}{c}412.1 \\
(360 \sim 459)\end{array}$ \\
\hline & - & $\begin{array}{c}48.6 \\
(42 \sim 54)\end{array}$ & $\begin{array}{c}40.0 \\
(35 \sim 45)\end{array}$ & $\begin{array}{c}40.2 \\
(34 \sim 45)\end{array}$ & $\begin{array}{c}382.1 \\
(336 \sim 430)\end{array}$ \\
\hline
\end{tabular}

すなわち、三ケ日人の寛骨臼の釷直径から、先ず大腿骨頭の大さを推定し（(37.9, 37.9)、 次に之を介して大腿骨最大長 (338.8) を知り、更に之を基にして身長を PEARSON の式か ら算出すると $145 \mathrm{~cm}$ となる。算定の基礎となつた腸骨は男性であるから、甚しい低身長と 称すべく、既に報告された牛川上腕骨は女性と推定され、その身長は $134.8 \mathrm{~cm}$ であつたか ら、やはり身長が著しく低かったが、その後、牛川採石場から紅村宏氏によつて発見された 大腿骨頭（牛川人骨 No. 2) は性別不明であるが、この骨頭は上記の三ケ日人寛骨臼に関節 させると、僅に大きすぎる。すおち牛川人骨 No. 2 は三ケ日人より僅に大きな身長をる

注 骨盤と大腿骨の報告は著者が別であるが、資料はともに慈急医大解剖学教室所蔵にかかる同一骨格 標本であるので、両者並列して表示した。 
つことになる。

KEITH (1927), WeIDENREICH（1941）は Neanderthal の性別判定には骨の大さが最良 であること述べているが、これは繩文時代人でも原則的にあてはまることである。

牛川人の大腿骨頭が三ケ日人男性より大形と推定されるとき、その性は女性と見なすより むしろ男性である公算が大きいように思える。かくて牛川人骨 No. 2 を暫定的に男性と見 做すと、大腿骨最大長 $(366.5 \mathrm{~mm})$ を介して、推定される身長は約 $149 \mathrm{~cm}$ であつて、や はり身長が著しく低い。これは対照として掲げた Düsseldorf の Neanderthal 人類の大さ に比して著しく小形である。

次に本骨片と明石市西八木発見の腰骨とを比較すると、ともに成年男性であり、また腸骨 高径と寛骨臼径もほぼ等しいか、または本骨片がむしろ小さい点で、ともに小柄の成年男性 であるが、両者を比較すると若干の相違がある。

すなおち、明石人骨は腸骨前縁が「く」の字形の彎曲を示すことなく、直線的であること、 腸骨前上棘と同前下棘が三ケ日人腸骨よりも更に発達が悪く、しかも両者の間隔、従つて腸 骨前縁の長さが短い。次宽骨臼の深さについては、明石人骨は三ケ日人骨より浅く、従つ て寛骨臼の後縁に拈ける坐骨体厚径は小さい。

\section{右大腿骨（人骨 No. 7)}

右大腿骨骨幹部を占める全長 $237 \mathrm{~mm}$ の骨片で、その近位端は Crista lateralis の頂点 の高さにあり、遠位端は下骨端線から測つてほぼ骨幹全長の $1 / 5$ ほど近位に破面がある。

保存状態は良好である。断端は不規則な破面に終るが、両断端から約 4 5 cm の範囲は食 肉動物の歯型が多数認られ、特に大腿骨稜の内外側唇とその間の膝窩平面上部には嚙痕が密 集している (Pl. III, 7a, b)。

骨片はほぼ中央で折れていたが、その破面でみると、髄腔は棈円形の断面をもち、矢状径 $13 \mathrm{~mm}$ 、横径 $11 \mathrm{~mm}$ であるが、その内面は石灰華によつて被覆されている。この石灰華の 厚さは前面では最高 $5 \mathrm{~mm}$ に達するが、後面では $1 \mathrm{~mm}$ に減じ、そのため髄腔は直径 $10 \mathrm{~mm}$

Table 4. Femur of Mikkabi Man.

\begin{tabular}{|c|c|c|c|c|c|c|}
\hline & & \multirow{2}{*}{ Max. length } & \multicolumn{3}{|c|}{ Mid-shaft of the femur } & \multirow{2}{*}{$\begin{array}{c}\text { Index } \\
\text { pilastricus }\end{array}$} \\
\hline & & & $\begin{array}{l}\text { Sagitt. } \\
\text { diam. }\end{array}$ & $\begin{array}{c}\text { Transv. } \\
\text { diam. }\end{array}$ & Circumf. & \\
\hline \multicolumn{2}{|l|}{ Sinanthropus $5(\hat{o}+\phi)$} & - & 25.5 & 29.4 & 85.5 & 86.3 \\
\hline Spy I & 우 & 426 & 29.0 & 29.0 & 97 & 100.0 \\
\hline $\begin{array}{l}\text { Neanderthal } \\
\text { (Düsseldorf) }\end{array}$ & $\delta$ & 439 & 31.0 & 29.5 & 94 & 105.1 \\
\hline Ordos man & 우 & 一 & 24.6 & 25.0 & 84.0 & 98.4 \\
\hline \multicolumn{2}{|l|}{ Upper cave man $6(\hat{\delta}+\phi)$} & - & $32.0 *$ & $28.1 *$ & $95 *$ & $125.6 * *$ \\
\hline Mikkabi man（三ケ日） & $\hat{o}$ & (390) & 29 & 24 & 83 & 120.8 \\
\hline Hirasaka man (平坂) & $\delta$ & $(436)$ & 32 & 26 & 91 & 123.1 \\
\hline Natsushima man（夏島） & $\delta$ & $?$ & 32 & 24 & 87 & 133.3 \\
\hline Yoshiko (吉胡) 22 & $\hat{o}$ & 412.9 & 30.2 & 26.0 & 89.8 & 116.7 \\
\hline Tsukumo (津雲) 13 & $\delta$ & 418.2 & 29.3 & 25.5 & 86.8 & 114.6 \\
\hline Medieval Japanese 69 & $\hat{\delta}$ & 419.9 & 27.2 & 26.8 & 86.0 & 102.5 \\
\hline Modern Japanese 132 & $\hat{\delta}$ & 412.1 & 27.6 & 26.3 & 83.7 & 105.4 \\
\hline
\end{tabular}

$$
\text { * } \delta 2 \text { 例の平均 ** } \hat{\delta}, \text { ㅇ } 6 \text { 例の平均 }
$$


の円形に縮小する。石灰華の表面を髄腔内に覘うと、概ね平滑であるが、詳細に見ると不規 則に走る堤防状の隆起の間は、大小の顆粒状の高まりて満たされるが、これは骨梁に相当し て石灰が沈着したためと考えられる。

本大腿骨片を他の完形なる繩文時代人骨を基礎にして復原すると、その最大長はせいぜい $390 \mathrm{~mm}$ であつて、これを越えることはないと推定される。しかも本人骨はその形質から疑 いもなく男性と認められるので、津雲 $418.2 \mathrm{~mm}$ 吉胡 $412.9 \mathrm{~mm}$ に比すれば短かく、その 身長を PEARSON の式より算出すると $154.6 \mathrm{~cm}$ となり、従つて低身長の部に属するという ベきである。

本人骨を最も特徵ずけるのは大腿骨稜の隆起が甚だ強いことで、骨幹の中央と推定される 部分に於ける横径、矢状径及び周径はそれぞれ $24 \mathrm{~mm} 、 29 \mathrm{~mm}$ 及び $83 \mathrm{~mm}$ であり、従つて Index pilastricus（柱状示数または中央骨幹横断示数）は 120.8 であり、これは Table 4 に示すよ 5 に北京人類、ホアンデルタール人類のそれを遙に凌駕して、化石現生人類とくに 周口店の上洞人や我国の繩文時代人に近い值であり、したがつてその柱状性は著しいものが あると云うべきである。

この大腿骨稜は遠位半で分離する内外唇のうち、内唇は僅にその存在が判別できる程度で あるが、外唇は高い櫛状隆起となり、これに伴いCrista femoris を境として、その内側面は 弱く凸彎すのに対して、外側面は凹彎を示すのみならず。Crista femoris を多少ながら内側 に向い変位せしめている。このことは M. vastus medialis に比して M. vastus lateralis が著しく強力であつたことを物語つている。

Table 5. Index of robusticity of the femur wall of the femur at the mid-shaft.

\begin{tabular}{|c|c|c|c|c|c|c|}
\hline & \multicolumn{2}{|c|}{ Sagitt. diam. } & \multicolumn{2}{|c|}{ Transv. diam. } & \multicolumn{2}{|c|}{ Index of the } \\
\hline & Shaft & Canal & Shaft & Canal & $\begin{array}{l}\text { Sagitt. } \\
\text { diam. }\end{array}$ & $\begin{array}{c}\text { Transv. } \\
\text { diam. }\end{array}$ \\
\hline Sinanthropus $\quad(4 \hat{\delta}, 1$ ㅇ $)$ & 24.4 & 8.68 & 28.3 & 8.13 & 37.6 & 32.9 \\
\hline Krapina I & 27.3 & 10.3 & 32.0 & 9.2 & 37.7 & 28.7 \\
\hline Spy II & 32.1 & 10.2 & 30.0 & 13.2 & 31.8 & 44.0 \\
\hline Upper cave man $I$ & 32.1 & 16.1 & 24.4 & 12.3 & 50.2 & 50.2 \\
\hline "I II & 35.1 & 15.4 & 23.2 & 10.2 & 43.8 & 43.6 \\
\hline Mikkabi man（三ケ日） & 29 & 13 & 24 & 11 & 44.8 & 45.8 \\
\hline Hirasaka man (平坂) & 32 & 14 & 26 & 10 & 43.8 & 38.5 \\
\hline Natsushima man (夏島) & 32 & 16 & 24 & 12 & 50.0 & 48.0 \\
\hline Modern man (European) & 27.2 & 13.4 & 24.4 & 11.9 & 49.4 & 48.0 \\
\hline
\end{tabular}

三ケ日人大腿骨を特徵ずけるものは骨幹緻密質が厚いこと、およびこれに応じて髄腔が比 較的に㷋いことである。これは骨幹中央とその位置での髄腔に於ける横径と矢状径の比で知 ることができる。その大さはTable 5 で明なように北京人類、ネアンデルタ人類には及ばな いが、周口店上洞人、繩文早期人に近い值であり、現代人の比ではない（Fig.5)。

以上を要約すると、本大腿骨から推定される身長は低身長に属し、著しい柱状性を有し、 頑丈である。さらに現生人類としては骨質が厚く、髄腔が诙い。

柱状大腿骨は人類進化史上、現生人類となつて初めて獲得したものと解せられ、この点で も頭骨形質から Homo sapiens と見なしたことと一致する所見である。然し厚い骨質と狹 


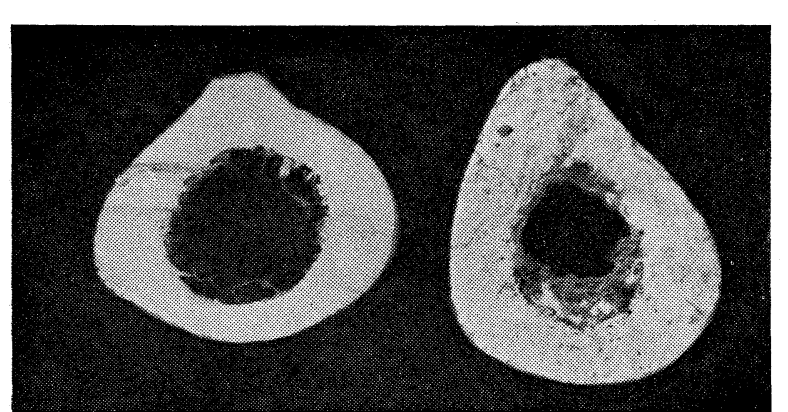

Fig. 5 Cross section of the mid-shaft of the femur (the top corresponds to the dorsal side of the bone).

Right: The femur from Mikkabi

Left: Modern Japanese
い髄腔とは Homo sapiens とし てもやや原始的であることを示唆 しているように見える。

以上述べた 7 片の人骨が由来し た三ケ日人の個体数に関し、採石 現場の堆積土の捨場から偶然発見 された右側頭骨 (No. 5) は今回の 発掘によつて発見された右頭頂骨 (No. 3) と正しく関節し、両者が 同一個休であることを示したが、 これらの骨片と前頭骨 (No. 1)。 左頭頂骨 (No. 4)、腸骨 (No. 6) とは $1 \mathrm{~m}$ 以内の範团で、注涪同

一の堆積層から発見されているばかりでなく、その北質も、これら総ての骨片が同一個体に 属することの可能性を否定するごときものではない。このように考えるとき、その性別は乳 様乫起、側頭線などの筇附着部、晹骨の形質から男性と推定される。

前頭骨（No. 2) は同名骨（No. 1）と側頭線などで異つて拈り、これと別個体に属してい ることは明である。をたその性は、その形質から女性と推測されることはすでに述べた。

成人の男性に属する右大腿骨は、他の 6 片の人骨とは若干、離れた地点から、土砂取片ず け中、人夫によつて発見されたので、他の人骨との関係を明白にすることは出来ない。した がつて差当り別の個体と見做している。

以上のよ5にして、現在までに発見された本遺跡からの人骨は差当り 3 体と見なしている が、その第 1 は No. 1，3〜6 を含む個体であつて、成人の男性であり、第 2 は No. 2 で成 人の女性、第 3 は No. 7 で成人の男性と見なされる。

\section{三ケ日人骨の古さ}

既に述べたように、腸骨（No.6）のみがアオモリゾウと共存して発見されたとの証言が あるだけで、今回の発掘では、人骨に伴つてその時代を明に決定し得る動物化石の発見はな かつたが、他の諸椧査によつて間接にその古さが推測される。

比重

本人骨群の比重は現代人や象牙のそれに比して著しく高く、注ぼ牛川石灰岩採石場発見の 上腕骨に等しいばかりでなく、三ケ日遺跡の洪積世獣骨のそれにも近い。これら人骨や獣骨 はその比重が石灰岩のそれに甚だ近い点で、よく化石した状態にあるといい得る (Table 6)。

このことは、現在より遙に隔る時代に由来することを莫然と暗示するものである。

弗素の含有量

三ケ日人骨の弗素含有量は別項の田辺義一博士の報文に明かなように、平均は $0.64 \%$ で あるから、現代人の $0.07 \%$ より著しく増加しているばかりでなく、地理的に本遺跡と同一 圏内にある繩文封代早期、前期遺物を含む嵩! 蛇穴石灰岩洞窟発掘の獣骨（小栗鉄次郎氏発 
掘）の $0.23 \%$ より著しく多い。一オ、その量は三ケ日人骨と同一の層から発掘された獣骨 と等しいばかりでなく、あ扔つのか、あおもりぞう等の洪積世動物化石とも大差がない。

Table 6. Specific gravity. Material Specific gravity

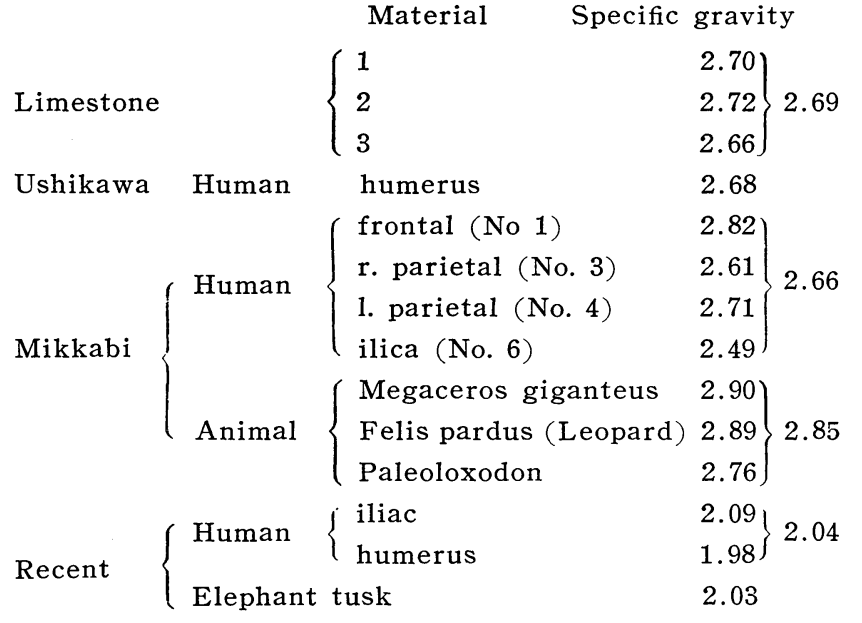

このことは人骨の属する時 代として、古生物学的に結 論される地質時代と異つた 時代を考える何らの理由る ない。

筆者は別項に述べてある ように、本遺跡の動物化石 が洪積世後期 $\left(\mathrm{J}_{2}\right)$ に由来 するとの高井の所見に鑑 み、人骨もまた同じ時代に 属するものと考えている。

このことはA洞発見の前 頭骨 (No. 2) も例外でな いことを物語るものであつ

て、狼の下顎がこれに伴つていたことはさらにその可能性を強める結果となるであろう。こ の点から考えて多分、繩文早期土器片は後の混入を考学させるが、これは C・D 区に问つて 連絡があるとともに、反対方向の開孔もあり、ともにA洞に向つて流入するように位置して いることから、その可能性は充分に考兄られる。

三ケ日人と牛川人との関係については、後者の資料が少いこと、伴出する化石動物に標準 化石がないことで詳でない。しかし田辺博士によると、弗素の含有量は牛川人上腕萳 $0.89 \%$ 、 同大腿骨 $0.96 \%$ で、三ケ日人骨と有意の差がある。

筆者は牛川人の上腕骨は繩文時代人とも現代日本人とも若干相違することを注意した（鈴 木，1959a，b)。このことを考慮に入れると、弗素含有量に有意差があることは、牛川人がよ り古いことを意味するものではないだろうか。このことに関連して、三ケ日人と同じ古さと 推定される浜北人の上腕骨 (末発表) はやはり牛川人上腕骨とやや形態を異にすることをこ こに附記する。

Homo sapiens としての三ケ日人

しからばこの洪積世後期の人類である三ケ日人は如何なる型の人類であるか。三ケ日人の 右側頭骨と右頭頂骨とを正しい位置に固定させると、乳様乫起から頭頂部にかけて、側面輪 廓は高く直立し、その形は Homo sapiens に特有な高い脳頭骨を想起させる(P1. II, 5)。

これに相当して前頭骨の眼窩上部の形態は、Torus supraorbitalis を示すことなく、独立 の 3 部分から成る Homo sapiens の型であり、側頭骨の乳様突起をはじめとして Tympanic plate, Crista zygomatica, Incisura mastoidea の形質も、正に Homo sapiens の 特徴である。また大腿骨が柱状であることも、Neanderthaloid 又はそれより原始的な型 の人類とは考えられない(P1. I, 2；II, 5)。

以上、三ケ日人の形質は Homo sapiens に特有なものばかりで、腸骨の形質もまたこれ 
に相反するものではない。即ち三ケ日人は化石現生人類である。

次にこの三ケ日人は、既知の日本の先史時代人とどの様な形質の異同があるか。

前頭骨形質、とくに復原される全形、側頭線の発達とその走行、側頭骨の乳様上櫛とその 前方の側頭窝の形態、さらに大腿骨の Pilaster 形成などの組合せは、古墳時代から現代に 至る日本人には認められないことであるが、之に対して繩文時代人には最も普遍的に認めら れる形質である。

これを要するに洪積计人類である三ケ日人は Homo sapiens に属するタイプで、これを 日本の既知の人類に類似を求むれば、繩文時代人に甚だよく似ているといえる。

この類繩文人型の三ケ日人は骨盤、大腿骨から按ずると、現代人に比して著しく小形のも のの如く、繩文時代人より身長が低かつた疑がある。これは既述の牛川人上腕骨 (No. 1) は女性と推定されたが、その長さは短かく、これを基にした身長は $134 \mathrm{~cm}$ と推定された。 また最近発見された男性の大腿骨頭（No. 2) も小形で、現代人と同じ比率を保つたとすれ ば、身長は $150 \mathrm{~cm}$ 前後と推定され、やはり甚だ低く、倭人の範疇に属する可能性がある。 嚙痕と骨の加工

右頭頂骨（No. 3) と右側頭骨（No. 5) とは正しく関節し、明に同一個体であるにもかか わらず、後者には何らの加工がないにもかかわらず、前者では骨片の周縁と外側面は人為的 に研磿されたあとがあつた。しかもこの両骨片とも食肉獣による嚙痕が認められたが、既に 述べたように、この頭頂骨上の踤痕は人が加工する前に加えられたものと判定された。また 同様な啮痕は大腿骨にも認められた。

このような啙痕の存在は繩文時代又はそれ以降の正しく埋葬された人骨には通常みられな いところで、わずかに鎌倉市材木座の中世人骨群に同一の状態が認められた。すなわち、こ れらの人骨にあつては、一個体分の骨格又はそれに近い状態で埋葬された人骨では、何らの 損傷がなかつたが、しばしば遭遇する大量の長管骨から成る人骨群では、そのほとんぞ全部 の骨に於て、その両端は食肉獣の踨痕とそれによる特殊な変形があり、その状態から、遺棄 された遺体を犬があさつた結果と推論した。

三ケ日人骨の場合も骨が鎌倉人骨と同じ状態にあることは、遺骨も後者と同じか又はこれ 飞近い状態に放置されたものと思われる。

多分、遺体はフィツンヤーに流入し、埋没する以前は、土中の埋葬ではなく、人の生活の 場に近く、容易に食肉獣の䬺食となり得る状態に放置され、その結果、頭骨は破壊して骨片 になつた。三ケ日人は何かの理由でこれら頭骨の一片を石器で形を整えた上、研櫋したの が、No. 3,4 骨片であつたと考觉る。

人の頭骨を何らかの目的から人為的に加工した例は旧石器時代から知られている。H. BreUIL 及び H. ObERMAIER (1909) はフランス Placard 洞に於て発見された Solutréen, Magdalénien に由来する人の頭骨杯、頭骨杓を記載しているが、その外表面には切痕があ り、辺縁には retouchesを認めた。

このような頭骨加工はその後の時代にも認められる。たとえば Kodiak Irland の Uyak 湾の “Our Point” て発掘された Pre-Koniag の遺骨の間には、頭骨杯、构があり、後者 の例として挙げられたもののなかには、三ケ日頭骨と同一部を示しているものがあるらしい (HRDRICKA, 1941)。 
更に時代が下つて、Tibet の Lama に於ては、人骨製の楽器を用いるのみならず、頭骨 杯や人の頭骨製の bead でできたロザリオも使われている (LAUFER, 1923)。

吾が国の繩文時代に於ても、加工された人骨の例は余山、中沢浜、稲荷山の諸貝塚や氷見 白山社洞窟の資料で報告されている（鈴木，1938, '41, '44)。

乙かも山本清（1955）、小片保氏（1958）は取鳥県講武村佐太貝塚（繩文時代中期）から発 見された興味ある人骨を報告している。この骨は径 $3.5 \mathrm{~cm}$ 涂どの、矢状縫合を含む右頭頂 骨前半部で、その形は不正五角形であるといらが、中央に直径 $5 \mathrm{~mm}$ の 2 個の小円孔が穿た れ、縁は磨滅しているところから小片氏は紐を通して身体に装着したろうといつている。

多分、三ケ日人骨も、上の佐太人骨と同一又はこれに近い意義をもつた骨器又はその未成品 と思われる。さらに骨片の由来について Trepanation を考光る人もあるが、吾が国では確 実な Trepanation の例はないので、他に求めねばならない。

既に述べたように骨片が広範囲に散在し、しかも食肉動物に嚙られて破損した骨片の一個 を加工したことから、遺棄された遺体の可能性がある。

この際、人骨を遺棄させた動機として、食人の可能性が考兄られないであろろか。

W. GIESELER（1952）は食人に関して各地、各時代の洪積世人類遺跡を検討した結果、共 通な遺骨の特徵とこて次のことを挙げている。それは遺骨に不足部が多いこと、残つている 骨に何らかの意味の損傷があること、人骨は広範囲に散乱し、しかも獣骨に混じて発見され ることである。三ケ日人骨を埋蔵したフィッンヤー内堆積はその成因に於て確に二次的なも のと思われ、直接上述の状態と比較はできないが、少くとも発掘された状態と骨の性状は食 人の結果、遺棄された後にフィッンヤー内に流入したと考觉ることも可能であろう。人骨加 工がしばしば食人または頭骨崇拝と結びついていることもこの考孚を強めるものである。

欧州の洪積世人類が食人の風習をもつていたことは Krapina, La Quina, Ehringsdorf の遺骨の状態からほぼ間違いないことであるし、東亜においても、Sinanthropus pekinensis に同じ風習があつたと信ぜられているが、その後の石器時代末期、又は金石併用時代に 由来すると思われる沙鍋屯の人骨にも食人を思わせる痕跡があつた。このような食人は先史 時代には地球上に広く行われていたが、筆者（1938）はわが国の繩文時代にも食人の風習が あつたことを人骨の埋葬状態と骨の切痕から述べたことがある。

このように考えてくると、三ケ日人の間にも食人風習が存在したとしても不思議なことで はないと思えるが、な挆将来の問題として残して执きたいと思う。

$$
\text { 三ケ日人の文化 }
$$

今日までのところ、三ケ日人の文化を推測させる資料としては、僅に加工された人の右頭 頂骨片があるだけで、石器その他の物件はない。この骨片は外側面の研磨に加えて、骨の周 縁とくに、乳様角 (Angulus mastoideus) の内外両側縁、Margo squamosus などには 鋭利な切削の痕が認められた。これは場所によつて長短の差はあるが、共通なことは一刀の むとに切り取られたような鋭利性であつて、繩文時代のそれと根本的に異つている。それは 金属器か、そうでなければ硬度の高い flint 又は chert の剥片で、はじめてなこ得るとこ ろと考えられる。

繩文時代の石器による痕は、鹿角や動物長管骨にしばしばその典型的なものが認められる 
ように、その痕の性状は鈍厚である。これは繩文時代石器刃部の形態が鈍厚であることに一 致して、必然的に起る結果である。

三ケ日人が上部洪積世人であるとすれば、その文化は日本の洪積世文化と見做されるいわ ゆる無土器文化の可能性がまず考兄れるところであるが、本文化の初期よりその末期まで、 剥片石器は最も普遍的な石器をなしている（SugIhaRA \& TozAwA, 1960 ; 芹沢, 1962)。

このことから考えると、人骨の加工の状態から、三ケ日人の文化は剥片石器を伴う、いわ ゆる無土器文化の或る型の文化であつた可能性が強い上うに思われる。

要 約

静岡県引佐郡三ケ日町只木の採石場から、筆者らによつて昭和 34 年以来、発掘により、或 いは偶然に発見された人骨は頭骨、四肢骨を合せて 7 片に上るが、目下のところ 3 体分と推 定される。これは成人男性 2 体、成人女性 1 体と見做している。三ケ日人骨の比重、弗素含 有量（田辺）は現代人骨に比し、甚だ大きく、本遺跡の洪積世動物と相違はない。しかも協 同研究者高井によると、動物化石から、その属する年代は洪積世後期と考兄られるので、人 骨もまた洪積世後期の人類と見做すことができる。

次に人骨の形質から、三ケ日人はホモ・サピエンスであつて、わが国の繩文時代人に似た 型である。つまり繩文時代人は洪積世人の形質の後継者と見なされる。しかし身体の大さは 繩文時代人より更に小さいらしく、男性で $150 \mathrm{~cm}$ 前後の身長が推測される。

本人骨の中には、食肉獣によつて㗪まれたものがあつたが、それらのうち右頭頂骨片は人 為的に加工され、しかも加工のない右側頭骨と正しく関節した。嚙痕を詳細に検討すること によつて、加工された時期は食肉動物によつて㖥まれた後に行われたものであることがわか つた。これらの点を考慮すると遺体は人の生活の場に近く動物の䬣食にまかされたと考兄ら れ、その動機として喰人の疑がもたれる。

加工の跡を細く検査するとき、加工のために使用された利器は、いわゆる無土器文化の剥 片石器の可能性が最も強いように思われる。

終りに、私どもは今回の調査に当つて、終始地元三ケ日町にお世話になつたが、とくに積 極的に援助された三ケ日町長堀口真隆氏、同助役石原茂登男氏 (現町長)、町議会議長高橋在 止氏、教育委員長二橋泰蔵氏、教育長中村秀吉氏をはじめとする町職員各位、また今回の発 掘に絶大な援助を与えられた県立三ケ日高校長内藤睦美氏をはじめ教職員、生徒諸氏に対し て厚く御礼を申します。な技今回の調査の発端を開き、その後も地元にあつて、常に私ども の調査の原動力ともなつた同校高橋佑吉氏に対し、哚い感謝と敬意を表するとともに、現場 にあつて今日な㨁接に協力されている事業主藤原三郎氏に対し心からの謝意を表します。

\section{文献}

新井正治, 1933：日本人骨盤の研究. 人類誌，48-5. p. 277-278.

BREUIt, H et OBERMAier, H., 1909: Crânes paléolithiques façonnés en coupes. L'Anthropologie, T. 20. p. 523-530.

GIESELER, W., 1952: Schädelverletzungen, Kannibalismus und Bestattungen im europäischen Paläolithikum. Naturwissenschaftliche Monatschrift "Aus der Heimat", 60. Jg. p. $161-173$.

GIUFFRIDA-RUGGERi, 1913: Über die endocranialen Furchen der A. meningea media beim Menschen. Z. Morph. Anthrop., Bd. 15, p. 401-412. 
HRDI,IčKA, AILš, 1941: Diseases of and artifacts on skulls and bones from Kodiak Island. Smithsonian Miscellaneous Collections, Vol. 101, No. 4. p. 1-14.

長谷部言人, 1948 : 明石市附近西八木最新世前期堆積出土人類腰骨 (石膏型) の原始性に就いて. 人類 誌, $60-1.32-36$ 頁.

石沢 命達, 1931 ：吉胡貝塚人人骨の人類学的研究. 第三部下肢骨. 人類誌, 46. 第一附録, 1-93賁. KEITH, Sir ARthuR, 1927: A report on the Galilee Skull.

清野謙 次. 平井 隆, 1928：津雲貝塚人人骨の人類学的研究。第四部 下肢解. 人類誌, 43 . 第四 附録 303-390 頁.

LAUFER, BERTHOLD, 1923: Use of human skulls and bones in Tibet. Field Museum of Natural History, Leaflet, No. 10. p. 1-16.

MARTin, R. \& SAtter, K., 1959: Lehrbuch der Anthropologie. Bd. 2. p. 1189.

MAtTígGKa, J., 1934: Homo predmostensis. Prague.

OGATA, T., 1958: Ein verarbeitetes menschliches Scheitelbeinstück im neolithischen Zeitalter in Japan. Yonago Acta Medica, Vol. 3. p. 14-19.

大 場 信 次, 1950：関東地方人大腿骨の人類学的研究. 慈恵医大解剖学教室業績集 第三輯. 1-44頁芹沢長介, 1962：旧石器時代の諸問題. 岩波講座, 日本歴史 1. 77-107頁.

Straus, W. L. 1960: The Subarcuate Fossa in Primates. Anat. Rec. Vol. 138, p. 93-102. Sugihara, S. \& TozawA, M., 1960: Pre-ceramic age in Japan. Acta asiatica, No. 1. 鈴木 学, 1938：日本石器時代人骨の利器による損傷に就て. 人類誌, 55-7. 315-347 頁.

一一, 1941：下総余山貝塚発見の切痕ある人骨について. 人類誌，56-7. 347-351 頁.

——, 1944：加工せる二個の石器時代人大腿骨について. 人類誌，59-1. 25-28 頁.

- - 1950：相模平坂貝塚早期（繩文式遺跡）の人骨について. 人類誌，61-3. 117-128 頁.

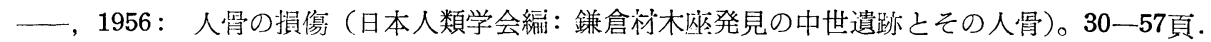

鈴 木 前, $1959 \mathrm{a}$ ：牛川鉱山で発見された些積世人類の上啘骨（シンポシウム：日本の洪積世人類の うち) 科学, 29. 398-402頁.

SUZUKI, H., 1959b: Entdeckung eines pleistzänen hominiden Humerus in Zentral-Japan.

1. Morphologische Untersuchung des Humerus. Anthrop. Anz., Jg. 23. p. 224-235.

_ 1960: Recent discoveries of Pleistocene Man in Japan. Extrait des Actes du VIe Congres Intern. des Sciences Anthropol. et Ethnol., Paris, T. 1. p. 705-711.

WEIDENREICH, F., 1941: The extremity bones of Sinanthropus pekinensis. Palaeontologia Sinica, Series D, No. 5. p. $14-54$.

--, 1943: The skull of Sinanthropus pekinensis; a comparative study on a primitive hominid skull. Palaeontologia Sinica, Series D, No. 10. p. 176-184.

㙃 汝 康, 1958：河套人類骨和股骨化石 Fossil human parietal bone and femur from Ordos, Inner Mogolia. 古脊椎動物学報, Vol. 2. p. 208-212.

山本 清, 1955：講武村内の二つの先实遺跡. 講武村誌, 4-13頁. 

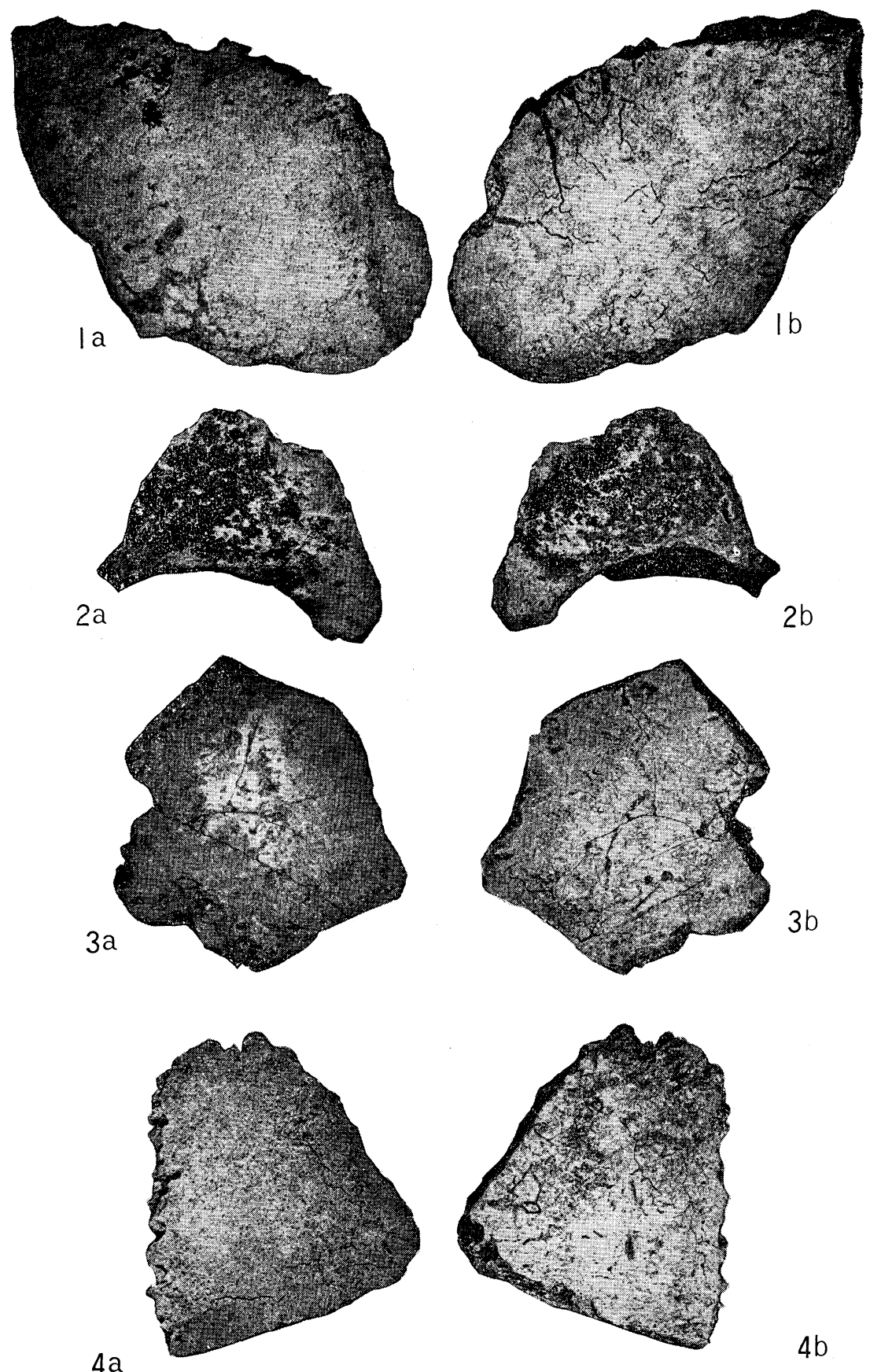

Plate I. Skull fragments of Mikkabi Man showing their outer (a) and inner (b) surfaces.

$1 \mathrm{a}, \mathrm{b}$ Frontal bone (No. 1).

$2 \mathrm{a}, \mathrm{b}$ Right supraorbital portion of the frontal bone (No. 2).

sa,b Right parietal bone (No. 3).

4 a,b Left parietal bone (No. 4). 

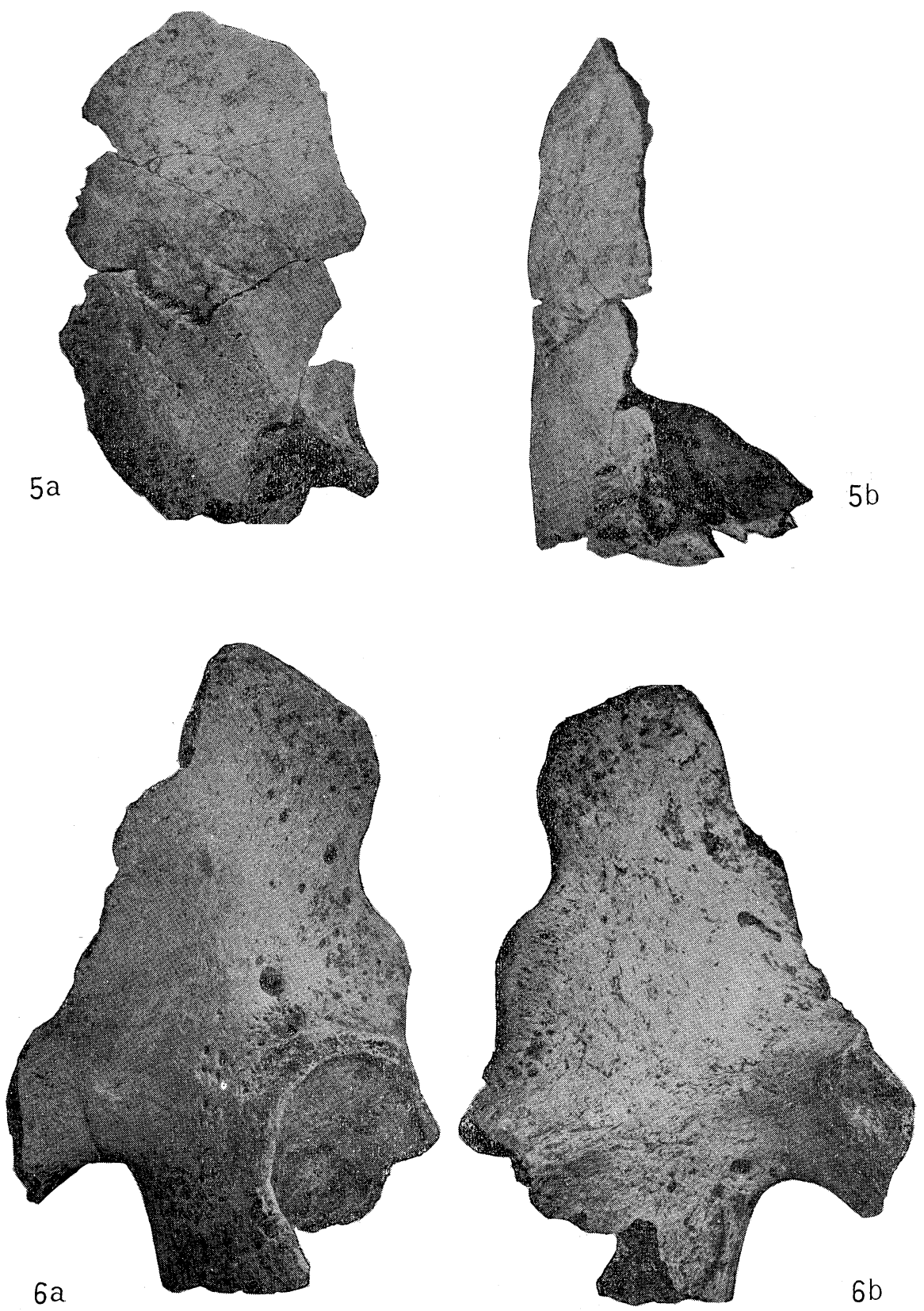

$2 / 3$

\section{Plate II.}

$5 \mathrm{a}, \mathrm{b}$ The both fragments of the parietal (No. 3) and the temporal (No. 5) bones of the right side fit together.
a: Lateral view
b: Frontal view

$6 \mathrm{a}, \mathrm{b}$ Outer (a) and inner (b) surfaces of the iliac bone (No. 6). 

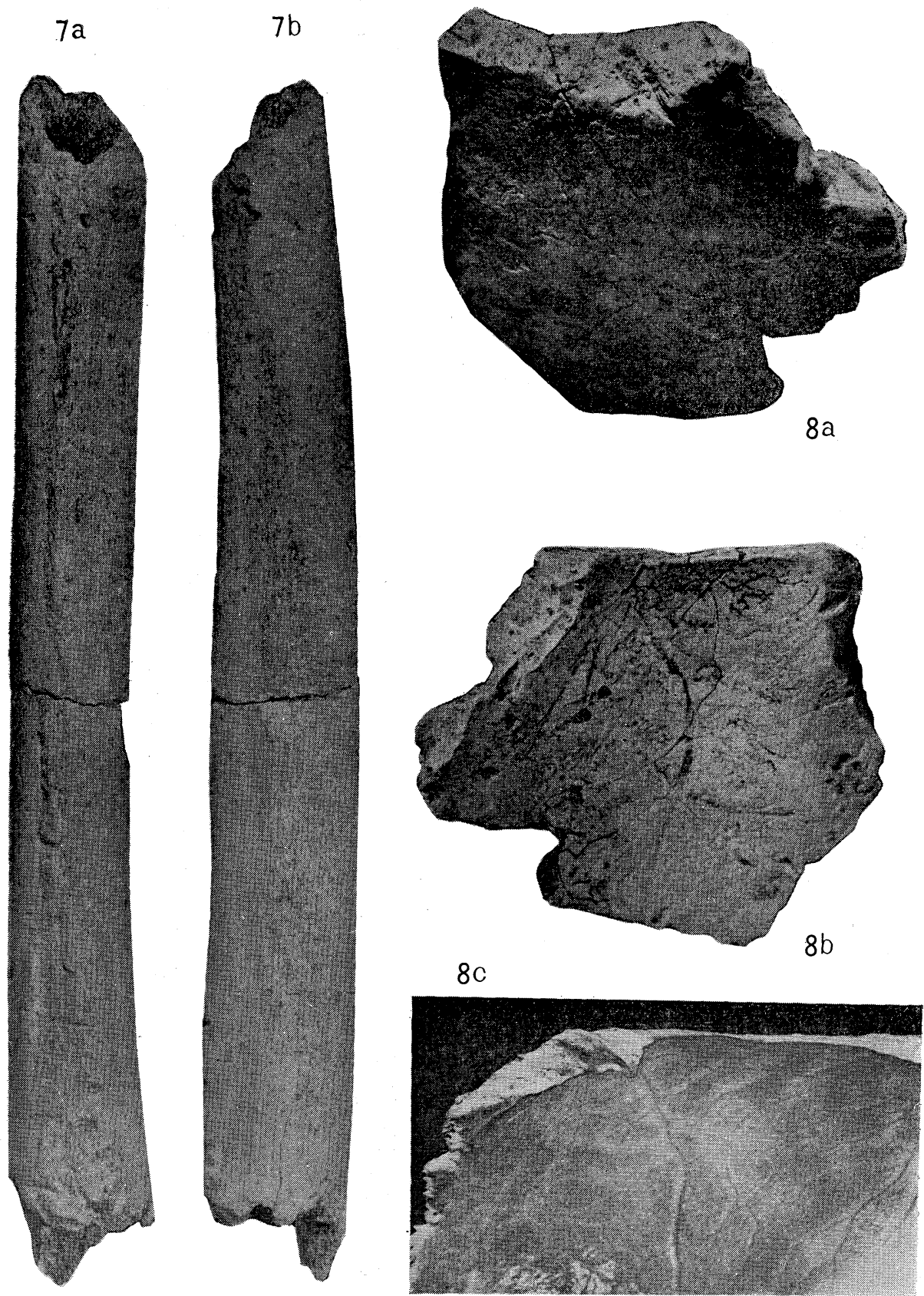

Plate III.

$7 \mathrm{a}, \mathrm{b}$ Posterior (a) and lateral (b) views of the right femur (No. 7$).(\times 2 / 3)$

$8 \mathrm{a}, \mathrm{b}$ Enlarged parietal bone (No.3) showing places of artificial polishing and cutting on the outer (a) and inner (b) surfaces. $(\times 1 / 1)$

$8 \mathrm{c}$ : The corresponding part of the same bone of the recent Japanese. $(\times 4 / 5)$ 